\title{
Studies on the Partition
}

\section{of Iron in Bone Marrow Cells}

\author{
Joseph V. Primosigh and E. Donnall Thomas \\ From the Department of Medicine, University of Washington School of Medicine and \\ the U. S. Public Health Service Hospital, Seattle, Washington 98144
}

A BSTRACT Canine marrow cells were incubated with transferrin-bound ${ }^{59} \mathrm{Fe}$, and the partition of cellular iron was studied by chromatographic and gel filtration methods. Splitting-off of iron from the stromal fraction was avoided by lysing the cells in Tris $\mathrm{HCl}$ buffer at $\mathrm{pH}$ 8.6. Cellular iron was divided into four major compartments : stroma, microsomes, main hemoglobin, and fraction $I$. The iron in fraction I was found in ferritin, heme proteins, and low molecular weight iron.

With incubation times of $3-10 \mathrm{~min},{ }^{59} \mathrm{Fe}$ appeared promptly in the main hemoglobin. The entry of ${ }^{59} \mathrm{Fe}$ into ferritin paralleled that of hemoglobin but was smaller in amount. When the marrow cells were incubated with ${ }^{59} \mathrm{Fe}$ for $15-20$ $\min$ and reincubated without radioactive iron, movement of ${ }^{59} \mathrm{Fe}$ into main hemoglobin was observed, and essentially all this iron came from the particulate fraction (stroma, mitochondria, and microsomes). In these chase experiments there was no change in the total quantity of ${ }^{59} \mathrm{Fe}$ in ferritin. There was no evidence of a significant hemoglobin precursor other than low molecular weight iron.

Depending upon concentration, lead was observed to inhibit cellular iron metabolism at several points : uptake of iron by the cell, movement of iron from stroma to the soluble intracellular compartment, and synthesis of hemoglobin. The most pronounced inhibitory effect of lead was always on hemoglobin synthesis with an increase in ferritin: hemoglobin ratio. Bipyridine appeared to trap intracellular ferrous iron and to inhibit synthesis of both hemoglobin and ferritin.

Received for publication 29 August 1967 and in revised form 21 February 1968.
It was concluded that iron moves from the stroma into the soluble intracellular compartment as low molecular weight iron, probably as a complex of ferrous iron with low molecular weight components of the cytoplasm, that serves as the source of iron for both hemoglobin and ferritin synthesis.

\section{INTRODUCTION}

Iron moves through the plasma bound to a plasma protein, transferrin. At the surface of the red cell precursor it is released from transferrin onto the cell membrane and is incorporated rapidly into hemoglobin (1-4). The mechanism of the movement of iron from the cell membrane to the site of hemoglobin synthesis is not understood. Several studies have indicated that iron enters a nonheme precursor before being incorporated into hemoglobin (3-7). Some reports have suggested that ferritin is an intracellular precursor of hemoglobin $(8,9)$. Zail, Charlton, Torrance, and Bothwell observed rapid incorporation of ${ }^{59} \mathrm{Fe}$ into the ferritin of bone marrow in vitro without a decrease in radioactivity of ferritin on continued incubation without ${ }^{50} \mathrm{Fe}(7)$. They inferred that ferritin was not an immediate precursor of hemoglobin. This report describes a study of cellular iron partition by chromatographic and gel filtration methods, together with observations of cellular iron kinetics and the effects of inhibitors of hemoglobin synthesis.

\section{METHODS}

Isotopes and counting. ${ }^{\circ} \mathrm{FeCl}_{3}$, specific activity $8-25$ $\mu \mathrm{c} / \mu \mathrm{g}$, was obtained from Abbott Laboratories, North Chicago, Ill. ${ }^{50} \mathrm{Fe}$ was bound to transferrin by incubation of $100 \mu \mathrm{c}$ of ${ }^{\circ} \mathrm{FeCl}_{3}$ for $20 \mathrm{~min}$ at $37^{\circ} \mathrm{C}$ with $25-50 \mathrm{ml}$ of 
heparinized plasma. The quantity of iron added was always less than the binding capacity of the serum. Radioactive iron was counted in a well scintillation counter. ${ }^{1}$

Marrow procurement. The canine marrow donor was sacrificed with pentobarbital. Marrow was obtained from the long bones and suspended in Ringer's solution. The marrow was sieved through a stainless steel tea strainer and then passed through a stainless steel screen with openings $200 \mu$ square (4). Fat was removed by centrifugation at $240 \mathrm{~g}$. The marrow was processed and used within $1 \mathrm{hr}$ after removal from the body.

Incubation of marrow cells. Incubations were carried out at $37^{\circ} \mathrm{C}$ in air with gentle shaking. The incubation medium was approximately $50 \%$ autologous plasma (with or without transferrin-bound ${ }^{59} \mathrm{Fe}$ ) in Hanks' solution at $\mathrm{pH} 7.6$ with $10,000 \mathrm{U}$ of penicillin, $60 \mu \mathrm{g}$ of streptomycin, and $5 \mathrm{mg}$ of glucose per $\mathrm{ml}$. The quantity of marrow incubated ranged from 5 to $30 \times 10^{\circ}$ nucleated cells, and the volume of incubation medium ranged from 35 to $100 \mathrm{ml}$. After incubation in ${ }^{50} \mathrm{Fe}$-containing medium, the reaction was stopped by rapid cooling to $0^{\circ} \mathrm{C}$, and the cells were washed five times with a 10-20-fold volume of Ringer's solution. In chase experiments, an aliquot of washed cells was reincubated for $75 \mathrm{~min}$ at $37^{\circ} \mathrm{C}$ in plasma-Hanks' solution without added ${ }^{59} \mathrm{Fe}$.

Incubation with lead. In some experiments lead acetate was added to the incubation medium. In other experiments, lead-containing cells were obtained by allowing an aliquot of marrow to stand at room temperature for $5 \mathrm{~min}$ in $50 \mathrm{ml}$ of saline containing $2 \times 10^{-4} \mathrm{M}$ lead acetate. The cells were then centrifuged at $240 \mathrm{~g}$ for 5 min, resuspended, and incubated under conditions identical for the aliquot of marrow cells not exposed to lead. Exposure to lead in this fashion produced a moderate inhibition of hemoglobin synthesis without disruption of all metabolic processes (3).

Lysis of cells and preparation of supernatant. In some experiments washed, packed cells were lysed by overnight exposure to 4 volumes of distilled water at $4^{\circ} \mathrm{C}$. In other experiments lysis was accomplished by a similar exposure to $0.01 \mathrm{~m}$ Tris $\mathrm{HCl}$ buffer at $\mathrm{pH}$ 8.6. The lysate was centrifuged at $34,800 \mathrm{~g}$ for $20 \mathrm{~min}$ to remove the large particle fraction composed of stroma and "mitochondria," here referred to as the stromal fraction. The stromal fraction was washed three times in 10 volumes of $0.01 \mathrm{M}$ Tris $\mathrm{HCl}$ buffer at $\mathrm{pH} 8.6$, and the supernatants were combined. The supernatant was centrifuged at 100 ,$000 \mathrm{~g}$ for $70 \mathrm{~min}$ to remove the "microsome" fraction. The clear red supernatant was referred to as "hemoglobin solution."

Chromatography on IRC-50. The hemoglobin solution was chromatographed on the cation exchange resin, Amberlite IRC-50, (Rohm and Haas, Philadelphia, Pa.) in two steps as previously described (4). The first fraction composed of heterogeneous compounds not adsorbed to IRC-50 was referred to as "fraction I." The hemoglobin eluted from IRC-50 was referred to as "main he-

1 Packard Auto-gamma Spectrometer, Series 410A, Packard Instrument Company, Inc., La Grange, Ill. moglobin." This fraction contained about $98 \%$ of the heme of the hemoglobin solution.

Chromatography on DEAE cellulose. Commercial DEAE cellulose ${ }^{2}$ was sieved through U. S. standard sieves, Nos. 20 and 100 . The material remaining in the No. 100 sieve was suspended in distilled water and freed from the fines by repeated decantation. The DEAE cellulose was then treated alternately with $0.1 \mathrm{~N} \mathrm{NaOH}$ and $0.1 \mathrm{~N} \mathrm{HCl}$ with intermediate washing with distilled water through three or four cycles ending on the $\mathrm{NaOH}$ phase. It was then resuspended in $0.01 \mathrm{M}$ acetate buffer at $\mathrm{pH}$ 5.6 with repeated adjustments of the $\mathrm{pH}$ with $\mathrm{HCl}$ and transferred to a $1 \times 40 \mathrm{~cm}$ column. The column was then washed with starting buffer until the effluent had the desired $\mathrm{pH}$. The sample of fraction $\mathrm{I}$ in a volume of 10 $30 \mathrm{ml}$ of $0.0067 \mathrm{M}$ monosodium phosphate with $0.0033 \mathrm{M}$ $\mathrm{KCN}$ was applied to the column. A linear gradient of increasing ionic strength and decreasing $\mathrm{pH}$ was used with a starting buffer of $0.01 \mathrm{M}$ acetate, $\mathrm{pH} 5.6$, and a limiting buffer of $0.01 \mathrm{M}$ acetate, $\mathrm{pH} 4.0$, containing $0.1 \mathrm{M}$ $\mathrm{NaCl}$. After collection of the first two peaks, the column was washed with $8 \mathrm{ml}$ of distilled water, a second gradient was applied with a starting buffer of $0.005 \mathrm{M}$ phosphate, $\mathrm{pH} 7.7$, and a limiting buffer of $0.05 \mathrm{M}$ phosphate, $\mathrm{pH}$ 7.7. When the third peak had been collected, a fourth peak was obtained by clearing the column with $0.5 \mathrm{M} \mathrm{KCl}$ in $0.05 \mathrm{M}$ phosphate at $\mathrm{pH}$ 7.7. Total recovery of radioactivity in the peaks from the DEAE columns was about $60 \%$.

Separation with Sephadex. Sephadex G-25, G-100, or G-200 ${ }^{3}$ was allowed to swell in $0.05 \mathrm{~m}$ Tris $\mathrm{HCl}$ buffer, $\mathrm{pH} \mathrm{7.7,} \mathrm{for} 24 \mathrm{hr}$ and freed of fines by repeated decantation. Columns of $2 \times 35$ or $2 \times 55 \mathrm{~cm}$ were filled with Sephadex and covered with a $2 \mathrm{~cm}$ disc of filter paper. Samples were applied in a volume not exceeding $8 \mathrm{ml}$ for the $35 \mathrm{~cm}$ column or $11 \mathrm{ml}$ for the $55 \mathrm{~cm}$ column. Gel filtration was carried out with an eluting buffer of $0.05 \mathrm{~m}$ Tris $\mathrm{HCl}$ at $\mathrm{pH}$ 7.7. In some experiments ethylenediaminetetraacetate (EDTA) was added to a final concentration of 0.01 or $0.02 \mathrm{~mole} / \mathrm{liter}$ to prevent low molecular weight iron from adhering to the column. Recovery of radioactivity from Sephadex columns was 60$80 \%$ without EDTA and $85-95 \%$ with EDTA.

Preparation of ferritin and rabbit antiferritin. Recrystallized ferritin was prepared from canine liver by the method of Granick (10). $8.8 \mathrm{mg}$ of ferritin in $2 \mathrm{ml}$ of Freund's adjuvant was injected intramuscularly into two rabbits, on two occasions, 41 days apart. Sera were collected 23 and 30 days later. Using a modified Ouchterlony double diffusion technique (11), the lowest detectable concentration of ferritin was $138 \mu \mathrm{g} / \mathrm{ml}$. Total ferritin was determined by precipitation with antibody as described by Zail, Charlton, Torrance, and Bothwell (7).

Starch-gel electrophoresis. Starch-gel electrophoresis was carried out at $\mathrm{pH} 8.6$ by a discontinuous buffer system as described by Poulik (12).

2 Carl Schleicher and Schuell Co., Keene, N. H.

3 Pharmacia Fine Chemicals Inc., Piscataway, N. J. 


\section{RESULTS}

Separation with DEAE. Bone marrow cells incubated with transferrin-bound ${ }^{59} \mathrm{Fe}$ took up iron rapidly. Study of the soluble portion of the lysate of these cells indicated that a part of the ${ }^{59} \mathrm{Fe}$ was not in heme and that the nonheme fraction could be separated by DEAE chromatography (4). Accordingly, a series of additional experiments was carried out, and a representative experiment is shown in Fig. 1. Canine marrow cells were incubated with transferrin-bound ${ }^{59} \mathrm{Fe}$ for $25 \mathrm{~min}$. The cells were washed with Ringer's solution and lysed with distilled water. The ultracentrifuged lysate was chromatographed on Amberlite IRC-50 to remove the main hemoglobin component (4). The unadsorbed protein mixture (fraction I) was separated by means of a DEAE column into four peaks (Fig. 1). Table I shows the relative activity of these peaks in four representative experiments where distilled water was used for lysis.

The first peak, emerging with the column volume, can be shown by starch-gel electrophoresis to contain at least nine different proteins, two of which contain heme. The ${ }^{59} \mathrm{Fe}$ in this peak is in the heme proteins as indicated by close agreement between the activity obtained by chromatography compared with the activity obtained by Myhre's method (13), which permits the differentiation of

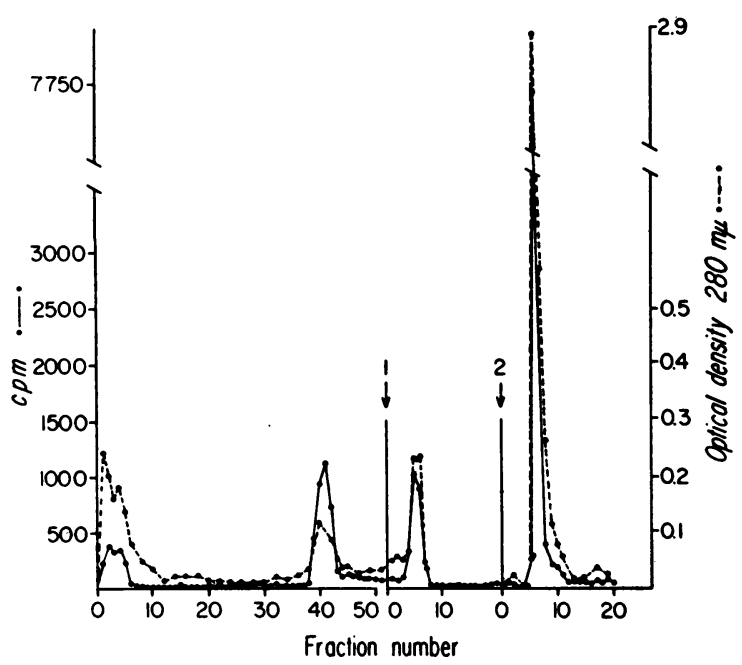

Figure 1 Separation of fraction I on DEAE. $30 \mathrm{ml}$ of fraction I containing $35,670 \mathrm{cpm}$ of ${ }^{80} \mathrm{Fe}$ and corresponding to $2.1 \times 10^{\circ}$ marrow cells was used. The first arrow indicates the change to the phosphate gradient. The second arrow indicates the change to $0.5 \mathrm{M} \mathrm{KCl}$. Column, $1 \times 40$
TABLE I

Separation of Fraction I by DEAE Chromatography

\begin{tabular}{ccccc}
\hline & \multicolumn{5}{c}{${ }^{50 \mathrm{Fe}}$} \\
\cline { 2 - 5 } $\begin{array}{c}\text { Experi- } \\
\text { ment }\end{array}$ & Peak 1 & Peak 2 & Peak 3 & Peak 4 \\
\hline 13 & 6.0 & 19.6 & 10.4 & 18.0 \\
15 & 7.2 & 12.8 & 3.3 & 44.9 \\
16 & 5.8 & 18.5 & 5.9 & 25.2 \\
18 & 6.7 & 11.0 & 8.0 & 36.5 \\
\hline
\end{tabular}

transferrin and ferritin from heme-containing proteins. This peak showed only a slight decrease in radioactivity in chase experiments. Microsomes appeared in peak 1 when they were not separated by ultracentrifugation. If transferrin were present, it would appear in this peak, since separate experiments showed that transferrin was not bound to DEAE under these conditions.

The second peak emerged with a steep ascending and a less steep descending side, with a tendency to tail, indicating incomplete elution. Starch-gel electrophoresis showed 10 or 11 proteins in this peak. The radioactivity was associated with Prussian blue positive zones in locations similar to crystalline dog liver ferritin. Agar gel diffusion showed reactions of identity between the radioactive compound in peak 2 and crystalline dog liver ferritin when reacted with rabbit antidog ferritin antiserum (Fig. 2).

The third peak contained at least eight electrophoretically different benzidine-negative proteins. The small amount of ${ }^{59} \mathrm{Fe}$ present in peak 3 did not decrease during chase experiments, and, therefore, the compounds in this peak were not characterized further.

The fourth peak showed the greatest decrease in activity in chase experiments. Separation of peak 4 on Sephadex G-200 showed it to contain some residual ferritin, a small fraction of ironcontaining proteins not completely excluded by the gel and a large fraction of lower molecular weight. Gel filtration on Sephadex G-25 indicated the latter fraction had a molecular weight of less than 5000 .

Change in the lysis procedure. The finding of a large low molecular weight fraction in the eluate from the DEAE column suggested that iron might 


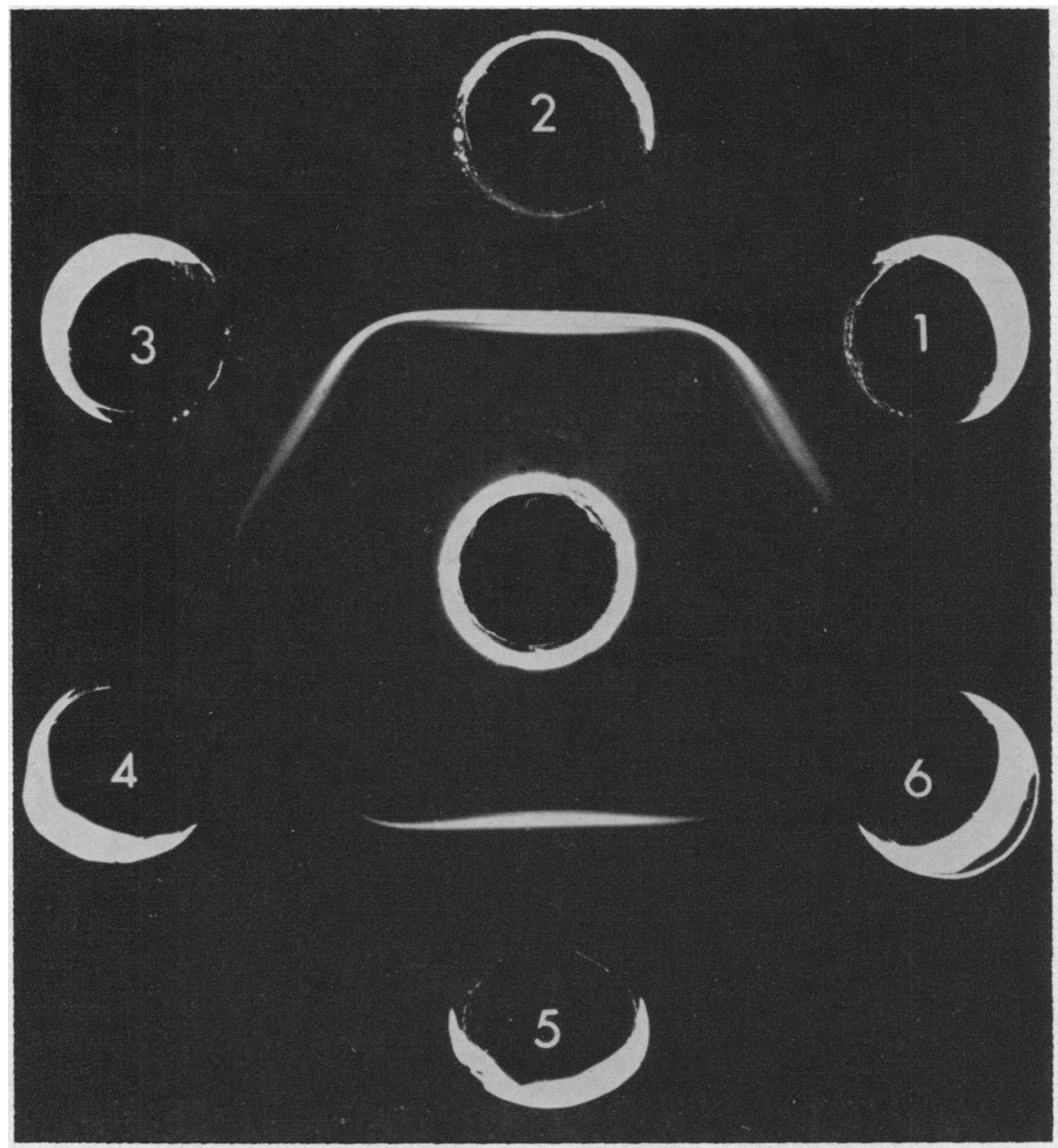

FIGURE 2 Identification of ferritin by agar gel diffusion. Center well, 1:8 rabbit antiserum against recrystallized dog liver ferritin. Wells 1,3 , and 5 , peak 2 as eluted from DEAE and concentrated 10-fold. Wells 2, 4, and 6, dog liver ferritin, 550, 275, and 138 $\mu \mathrm{g} / \mathrm{ml}$, respectively.

be split off from other compounds by exposure to relatively low $\mathrm{pH}$. During lysis of cells with distilled water the $\mathrm{pH}$ was found to be in the range of from 5.6 to 6.0. Since Cawley, Goodwin, Schneider, and Eberhardt (14) identified transferrin in the lysate of human erythrocytes, and since Laurell (15) observed that transferrin-bound iron dissociates below $\mathrm{pH} 7.2$, it appeared desirable to avoid a similar iron-protein dissociation by lysis at a higher $\mathrm{pH}$. Accordingly, lysis was carried out with $0.01 \mathrm{M}$ Tris $\mathrm{HCl}$ buffer at $\mathrm{pH} 8.6$, with a final $\mathrm{pH}$ of 8.2 , and was compared to lysis with distilled water (Table II). Lysis with buffer gave much less iron in fraction I. Fractionations of the ultracentrifuged lysate in Sephadex G-100 showed a two- to tenfold increase in the low molecular weight iron fraction in distilled water lysates, as compared with the buffer lysates. There was also an increase in the amount of iron in the main hemoglobin fraction with buffer lysis, due to a better elution of hemoglobin from the microsome pellet. Lysis with distilled water for $15 \mathrm{~min}$ or for $16 \mathrm{hr}$ gave similar results.

Separation with Sephadex. Sephadex columns were utilized to obtain separation of the lysates and of fraction I with the very mild condition of gel filtration at a $\mathrm{pH}$ of 7.7. Fig. 3 illustrates the separation of the ultracentrifuged lysate of equal aliquots of marrow after $20 \mathrm{~min}$ incubation with transferrin-bound ${ }^{59} \mathrm{Fe}$ and after 75 min additional 
TABLE II

Comparison of the Per Cent of ${ }^{59} \mathrm{Fe}$ in Different Fractions after Lysis of Cells with Distilled Water or with $0.01 \mathrm{M}$ Tris- $\mathrm{HCl}$ Buffer at $\mathrm{pH} 8.6$

\begin{tabular}{|c|c|c|c|c|}
\hline & \multicolumn{4}{|c|}{${ }^{69} \mathrm{Fe}$} \\
\hline & Stroma & $\begin{array}{l}\text { Micro- } \\
\text { somes }\end{array}$ & $\begin{array}{l}\text { Main } \\
\text { hemo- } \\
\text { globin }\end{array}$ & $\begin{array}{c}\text { Fraction } \\
\text { I }\end{array}$ \\
\hline & \multicolumn{4}{|c|}{$\%$} \\
\hline Lysis with $\mathrm{H}_{2} \mathrm{O}$ & 19 & 33 & 29 & 19 \\
\hline Lysis with buffer & 27 & 21 & 41 & 10 \\
\hline
\end{tabular}

incubation without ${ }^{59} \mathrm{Fe}$. EDTA, 0.01 mole/liter final concentration, was added to the lysate to prevent the nonprotein iron from sticking to the column. From these aliquots the total radioactivity for each peak was calculated.

Immunoprecipitation showed the ${ }^{59} \mathrm{Fe}$ in peak I to be composed principally of ferritin. About $80 \%$ of the radioactivity could be precipitated by antiferritin antiserum. This peak contained a total of $13,900 \mathrm{cpm}$ of ${ }^{59} \mathrm{Fe}$ before the chase and 14,500 cpm after the chase. The total radioactivity in the

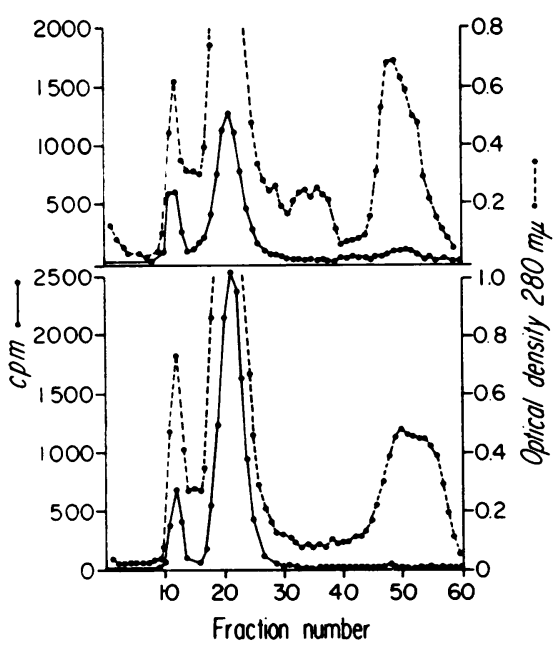

FIGURE 3 Separation of the ultracentrifuged supernatant of a marrow lysate on Sephadex G-100. $17.7 \times 10^{\circ}$ nucleated marrow cells were incubated for $20 \mathrm{~min}$ at $37^{\circ} \mathrm{C}$ in $25 \mathrm{ml}$ of autologous plasma and $20 \mathrm{ml}$ of Hanks' solution containing $100 \mu \mathrm{c}$ of transferrin-bound ${ }^{59} \mathrm{Fe}$. The upper portion of the figure shows the iron partition of an aliquot obtained at the end of the $20 \mathrm{~min}$ incubation. The lower portion of the figure shows the iron partition of an equal aliquot obtained after an additional incubation of $75 \mathrm{~min}$ without ${ }^{50} \mathrm{Fe}$. Lysates were prepared in Tris $\mathrm{HCl}$ buffer. Column, $2 \times 55 \mathrm{~cm}$; flow rate, $18 \mathrm{ml} / \mathrm{hr}$; fraction volume, $3.6 \mathrm{ml}$. ferritin of the lysate before ultracentrifugation was also determined by immunoprecipitation. Total ferritin radioactivity was $31,700 \mathrm{cpm}$ before the chase and $32,700 \mathrm{cpm}$ after the chase. The difference in the total ferritin activity and in the ferritin activity from peak I represents the loss of ferritin into the microsome fraction during ultracentrifugation. Peak I, therefore, does not represent a quantitative determination of ferritin. In this and several other experiments the activity of peak I was found to represent about $40-45 \%$ of the activity of the total ferritin.

Peak II consisted mainly of hemoglobin with a minor fraction composed of ${ }^{59} \mathrm{Fe}$ in proteins that appear in peaks 1 and 3 of the DEAE separation. This peak contained a total of $60,300 \mathrm{cpm}$ before and $106,300 \mathrm{cpm}$ after the chase.

Peak III contained low molecular weight iron with a total of $9300 \mathrm{cpm}$ before and $2010 \mathrm{cpm}$ after the chase. In separate experiments with added inorganic ${ }^{59} \mathrm{Fe}$ it was found that recovery of peak III from the column averaged about $80 \%$ even with excess EDTA.

Fig. 4 illustrates the separation of fraction $I$ on Sephadex G-200 before and after a chase. Peak I, the ferritin fraction, showed no change in radioactivity during the chase. Since the main hemoglobin had been removed, the second peak contained relatively little radioactivity. It also showed no significant change in radioactivity during the chase. Peak III, low molecular weight iron, decreased from 4020 to 1040 .

Characterization of the low molecular weight iron fraction. As indicated above peak 4 from the DEAE columns and peak III obtained by gel filtration contained ${ }^{59} \mathrm{Fe}$ with a molecular weight of less than 5000, as shown by its retention in Sephadex G-25. Comparison of this low molecular weight iron with inorganic ferric iron showed identical behavior on the Sephadex columns. Like inorganic iron, it could be separated from the hemoglobin solution at $\mathrm{pH} 7.0$ by pressure ultrafiltration through cellophane, it was not precipitated by saturated ammonium sulphate at $\mathrm{pH}$ 5.0, and it was precipitated by 8 -hydroxy-quinoline at pH 7.7 (with ferric ammonium sulfate as carrier). That this "inorganic iron" fraction was not adsorbed to protein is indicated by the fact that it did not move with proteins on gel filtration in the absence of EDTA, and by the fact that it could 


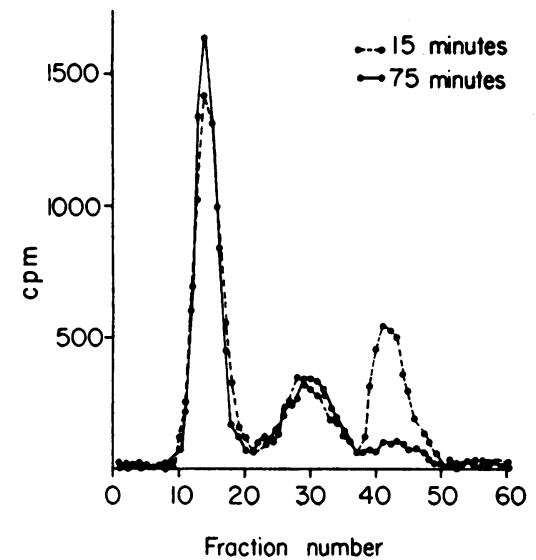

FIgURE 4 Separation of fraction I on Sephadex G-200. $6.9 \times 10^{\circ}$ nucleated marrow cells were incubated for $15 \mathrm{~min}$ at $37^{\circ} \mathrm{C}$ in $17 \mathrm{ml}$ of autologous plasma and $20 \mathrm{ml}$ of Hanks' solution containing $100 \mu \mathrm{c}$ of transferrin-bound ${ }^{80} \mathrm{Fe}$. An aliquot of this marrow was reincubated for an additional $75 \mathrm{~min}$ in the absence of ${ }^{50} \mathrm{Fe}$. Lysates were prepared in Tris $\mathrm{HCl}$ buffer and ultracentrifuged, and fraction I was obtained from IRC-50 columns. Fraction I from aliquots before and after the chase was then separated on Sephadex G-200. Column, $2 \times 55 \mathrm{~cm}$; flow rate, $8.6 \mathrm{ml} / \mathrm{hr}$; fraction volume, $4.3 \mathrm{ml}$.

be separated from proteins by ultrafiltration. These observations do not exclude complex formation by the intracellular ${ }^{59} \mathrm{Fe}$ with low molecular weight compounds, such as amino acids (16).

Fractionation of cellular iron. The technique described permitted the separation of cellular iron into four major compartments: Stroma, microsomes, main hemoglobin, and fraction I. Fraction I could be further divided into three parts: ferritin, heme proteins, and low molecular weight iron. Table III shows the uptake of transferrin bound ${ }^{59} \mathrm{Fe}$ into each of these compartments after $15 \mathrm{~min}$ incubation and the transfer of ${ }^{59} \mathrm{Fe}$ between compartments upon a further incubation of $75 \mathrm{~min}$ without ${ }^{59} \mathrm{Fe}$. Movement of ${ }^{59} \mathrm{Fe}$ into main hemoglobin during the chase is evident. Essentially all this iron came from the particulate compartment (stroma, mitochondria, and microsomes). The ${ }^{59} \mathrm{Fe}$ in fraction I decreased only slightly. Radioactivity of the low molecular weight iron in fraction I decreased moderately, but there was no change in the ferritin fraction (peak I) nor in the heme-protein fraction (peak II).

In order to look for an early precursor of hemoglobin, fractionation of intracellular iron after periods of incubation of from 3 to $10 \mathrm{~min}$ was studied in several experiments. Table IV shows the partition of iron in marrow from a normal dog, a dog made iron deficient by bleeding and a dog given Imferon ( $1 \mathrm{~g}, 3 \mathrm{wk}$ before sacrifice) to increase iron stores. The iron-deficient marrow showed a greater ${ }^{59} \mathrm{Fe}$ uptake with some increase in fraction I, but there was otherwise no significant difference. In the three experiments shown in Table IV the lysate was ultracentrifuged in order to separate microsomes. Since ultracentrifugation results in the loss of ferritin, two additional experiments were performed in which total ferritin was determined by immunoprecipitation. The results, Table V, show that hemoglobin and ferritin take up ${ }^{59} \mathrm{Fe}$ in parallel. Neither a delay in the appearance of the label in hemoglobin nor a buildup of ${ }^{59} \mathrm{Fe}$ in ferritin preceeding hemoglobin could be detected. Hemoglobin always showed a greater uptake of ${ }^{59} \mathrm{Fe}$ than ferritin.

Influence of lead on intracellular iron partition. Table VI shows the results of a series of experiments designed to investigate the effects of lead on intracellular iron partition. In the first experiment aliquots of bone marrow were incubated for $45 \mathrm{~min}$ in the presence of transferrin-bound iron without lead and with $7 \times 10^{-4} \mathrm{M}$ lead. This relatively high concentration of lead caused a marked

TABLE III

Partition of ${ }^{59} \mathrm{Fe}$ into Various Compartments

\begin{tabular}{|c|c|c|c|c|}
\hline & \multicolumn{4}{|c|}{ Normal dog } \\
\hline & \multicolumn{2}{|c|}{15 min incubation } & \multicolumn{2}{|c|}{$\begin{array}{l}\text { Additional } 75 \\
\text { min incubation } \\
\text { with "cold" iror }\end{array}$} \\
\hline & $c p m$ & $\%$ & $c p m$ & $\%$ \\
\hline $\begin{array}{l}\text { Total cpm in washed } \\
\text { cells }\end{array}$ & 784,000 & & 710,810 & \\
\hline Stroma & 368,325 & 47 & 215,050 & 30 \\
\hline Microsomes & 128,950 & 16 & 117,070 & 16 \\
\hline Main hemoglobin & 226,600 & 29 & 329,275 & 46 \\
\hline Fraction I & 60,130 & 8 & 49,410 & 7 \\
\hline \multicolumn{5}{|l|}{$\begin{array}{l}\text { Subfractions of } \\
\text { fraction I from } \\
\text { Sephadex G-100 }\end{array}$} \\
\hline Peak I (ferritin) & 34,390 & 4.3 & 34,875 & 4.9 \\
\hline Peak II & 5,125 & 0.6 & 5,405 & 0.7 \\
\hline $\begin{array}{l}\text { Peak III (low } \\
\text { molecular weight) }\end{array}$ & 11,720 & 1.4 & 7,060 & 0.9 \\
\hline
\end{tabular}


TABLE IV

Partition of ${ }^{59} \mathrm{Fe}$ into Various Compartments after Short Incubation Time

\begin{tabular}{|c|c|c|c|c|c|c|c|c|c|c|c|c|}
\hline \multirow{3}{*}{ Time of incubation } & \multicolumn{4}{|c|}{ Normal dog* } & \multicolumn{4}{|c|}{ Iron-deficient dog* } & \multicolumn{4}{|c|}{ Dog given iron* } \\
\hline & \multicolumn{2}{|c|}{$5 \mathrm{~min}$} & \multicolumn{2}{|c|}{$10 \mathrm{~min}$} & \multicolumn{2}{|c|}{$3 \min$} & \multicolumn{2}{|c|}{$8 \mathrm{~min}$} & \multicolumn{2}{|c|}{$3 \mathrm{~min}$} & \multicolumn{2}{|c|}{$8 \mathrm{~min}$} \\
\hline & $c p m$ & $\%$ & $c p m$ & $\%$ & $c p m$ & $\%$ & $c p m$ & $\%$ & $c p m$ & $\%$ & $c p m$ & $\%$ \\
\hline $\begin{array}{l}\text { Total cpm in } \\
\text { washed cells }\end{array}$ & 33,816 & & 61,615 & & 87,167 & & 183,955 & & 29,669 & & 59,360 & \\
\hline Stroma & 14,809 & 43.8 & 21,319 & 34.6 & 47,365 & 52.0 & 86,680 & 47.1 & 18,688 & 63.0 & 31,312 & 52.7 \\
\hline Microsomes & 4,182 & 12.4 & 10,472 & 16.9 & 6,203 & 7.2 & 10,800 & 5.8 & 1,506 & 5.0 & 5,330 & 8.9 \\
\hline Main hemoglobin & 9,251 & 27.4 & 18,702 & 30.3 & 21,499 & 24.6 & 55,692 & 30.2 & 6,709 & 22.6 & 18,311 & 30.8 \\
\hline Fraction I & 5,574 & 16.5 & $-11,122$ & 18.1 & 12,093 & 15.0 & 30,786 & 16.7 & 2,766 & 9.3 & 4,407 & 7.4 \\
\hline \multicolumn{13}{|l|}{$\begin{array}{l}\text { Subfractions of } \\
\text { fraction I on } \\
\text { Sephadex G-100 }\end{array}$} \\
\hline Peak I & 3,735 & 11.1 & 8,201 & 13.3 & 4,434 & 5.1 & 7,004 & 3.8 & 1,648 & 5.5 & 2,430 & 4.0 \\
\hline Peak III & 963 & 2.8 & 1,461 & 2.4 & 3,392 & 3.8 & 10,550 & 5.7 & 890 & 3.0 & 1,113 & 1.8 \\
\hline
\end{tabular}

* Corrected to correspond to $1 \times 10^{9}$ marrow cells.

TABLE V

Distribution of ${ }^{59} \mathrm{Fe}$ in the Supernatants of Marrow Lysates

\begin{tabular}{|c|c|c|c|c|c|c|c|c|}
\hline \multirow{3}{*}{ Time of incubation } & \multicolumn{4}{|c|}{ Experiment 1* } & \multicolumn{4}{|c|}{ Experiment 2* } \\
\hline & \multicolumn{2}{|c|}{$3 \mathrm{~min}$} & \multicolumn{2}{|c|}{$8 \mathrm{~min}$} & \multicolumn{2}{|c|}{$3 \mathrm{~min}$} & \multicolumn{2}{|c|}{$8 \mathrm{~min}$} \\
\hline & $c p m$ & $\%$ & $c p m$ & $\%$ & $c p m$ & $\%$ & $c p m$ & $\%$ \\
\hline Supernatant $\ddagger$ & 28,019 & 100 & 40,999 & 100 & 13,577 & 100 & 18,447 & 100 \\
\hline Main hemoglobin & 8,160 & 29.1 & 12,560 & 30.6 & 6,550 & 48.1 & 11,866 & 64.1 \\
\hline Total ferritin§ & 1,344 & 4.8 & 3,279 & 8.0 & 2,253 & 16.6 & 2,840 & 15.4 \\
\hline
\end{tabular}

* Corrected to correspond to $1 \times 10^{9}$ marrow cells.

$\ddagger$ Obtained without ultracentrifugation.

$\S$ Determined by immunoprecipitation.

TABLE VI

The Effect of Lead on Cellular ${ }^{59} \mathrm{Fe}$ Partition

\begin{tabular}{|c|c|c|c|c|c|c|c|c|c|c|c|c|c|c|}
\hline \multicolumn{2}{|c|}{ Experiment } & \multirow{2}{*}{$\frac{\text { Time }}{\min }$} & \multicolumn{2}{|c|}{ Total uptake } & \multicolumn{2}{|c|}{ Stroma } & \multicolumn{2}{|c|}{ Microsomes } & \multicolumn{2}{|c|}{$\begin{array}{c}\text { Main } \\
\text { hemoglobin }\end{array}$} & \multicolumn{2}{|c|}{ Ferritin } & \multicolumn{2}{|c|}{$\begin{array}{l}\text { Low molecular } \\
\text { weight iron }\end{array}$} \\
\hline & & & $c p m$ & $\%$ & $c p m$ & $\%$ & cpm & $\%$ & $c p m$ & $\%$ & $c p m$ & $\%$ & $c p m$ & $\%$ \\
\hline \multirow[t]{2}{*}{ I } & Control & 45 & $1,163,000$ & 100 & 429,000 & 36.8 & 212,000 & 18.2 & 381,000 & 32.7 & 91,300 & 7.8 & - & - \\
\hline & $7 \times 10^{-4} \mathrm{~Pb}$ & 45 & 234,000 & 100 & 119,000 & 50.8 & 48,000 & 20.5 & 27,400 & 7.4 & 28,000 & 12.0 & - & - \\
\hline \multirow[t]{2}{*}{ II } & Control & 45 & $2,011,000$ & 100 & 601,700 & 29.9 & 428,000 & 21.3 & 755,000 & 37.5 & 76,500 & 3.8 & 27,500 & 1.4 \\
\hline & $2 \times 10^{-4} \mathrm{~Pb}$ & 45 & $1,802,000$ & 100 & 799,400 & 44.3 & 741,700 & 41.2 & 269,700 & 14.9 & 165,200 & 9.2 & 76,400 & 4.2 \\
\hline \multirow[t]{2}{*}{ III } & Control & 45 & 497,400 & 100 & 194,600 & 39.1 & 73,300 & 14.7 & 192,600 & 38.7 & 26,400 & 5.3 & 10,300 & 2.1 \\
\hline & $2 \times 10^{-4} \mathrm{~Pb}$ & 45 & 509,200 & 100 & 245,900 & 48.3 & 138,500 & 27.2 & 74,500 & 14.6 & 37,100 & 7.3 & 14,400 & 2.8 \\
\hline \multirow[t]{2}{*}{ IV } & Control & 45 & $1,000,000^{*}$ & 100 & 657,300 & 65.7 & 112,000 & 11.2 & 148,700 & 14.8 & 104,800 & 10.4 & 11,000 & 1.1 \\
\hline & $2 \times 10^{-4} \mathrm{~Pb}$ & 45 & $1,000,000^{*}$ & 100 & 728,000 & 72.8 & 124,400 & 12.4 & 73,500 & 7.4 & 78,700 & 7.9 & 15,100 & 1.5 \\
\hline \multirow[t]{2}{*}{ IV } & Control & 90 & $1,000,000^{*}$ & 100 & 621,200 & 62.1 & 120,900 & 12.1 & 161,300 & 16.1 & 134,900 & 13.5 & 10,900 & 1.1 \\
\hline & $2 \times 10^{-4} \mathrm{~Pb}$ & 90 & $1,000,000^{*}$ & 100 & 699,800 & 69.9 & 147,300 & 14.7 & 95,600 & 9.6 & 108,100 & 10.8 & 11,600 & 1.2 \\
\hline
\end{tabular}

* Torrected for minor differences in the aliquots of the cell suspension. 
reduction in total uptake of radioactive iron by all the iron-containing fractions including stroma. Lead caused a relative accumulation of iron in stroma and ferritin with marked inhibition of the entrance of iron into hemoglobin.

The second and third experiments (Table VI) were similar to the first experiment, except that the marrow cells were exposed to $2 \times 10^{-4} \mathrm{M}$ lead for $5 \mathrm{~min}$ at room temperature and then removed from the lead-containing medium. Exposure to lead in this fashion produced a moderate inhibition of hemoglobin synthesis without disruption of metabolic processes. The total uptake of iron by the control and the lead-exposed cells was virtually identical, but in the presence of lead there was an increased proportion of iron in the stroma, microsomes, and ferritin with a corresponding decrease of iron in the main hemoglobin fraction. The low molecular weight iron fraction was also slightly increased in the presence of lead. Fig. 5 shows the separation of the lysate on Sephadex G-200 for the second experiment.

In the fourth experiment bone marrow cells were incubated for $20 \mathrm{~min}$ in the presence of transferrin-bound iron. At the end of this period the cells were washed and divided into four equal aliquots; two aliquots were exposed for $5 \mathrm{~min}$ to $2 \times 10^{-4}$ M lead acetate and two aliquots served as control. The control and the lead-exposed aliquots were then incubated for an additional 45 or 90 min. In this chase experiment, the initial total uptake was, of course, identical. As shown in Table VI, movement of iron from the stromal fraction was inhibited by lead with a corresponding inhibition of hemoglobin synthesis and ferritin synthesis. However, the inhibition of hemoglobin

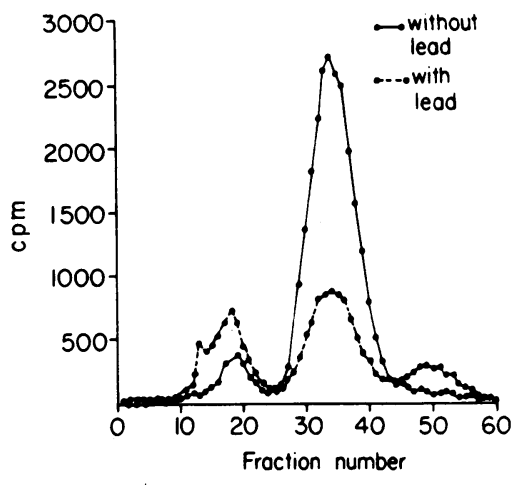

Figure 5 Separation on Sephadex G-200 of the supernatant of marrow lysates obtained with and without exposure to lead. Two aliquots of marrow were prepared, each containing $11 \times 10^{\circ}$ nucleated cells. 1 aliquot was exposed to $2 \times 10^{-4} \mathrm{M}$ lead for $5 \mathrm{~min}$. Each aliquot was then incubated for $45 \mathrm{~min}$ in $25 \mathrm{ml}$ of autologous plasma and $12 \mathrm{ml}$ of Hank's solution containing $50 \mu \mathrm{c}$ of transferrinbound ${ }^{50} \mathrm{Fe}$. Ultracentrifuged lysates were prepared with Tris $\mathrm{HCl}$ buffer. Equal aliquots of the lysates were separated on Sephadex G-200. The aliquot without lead contained $35,200 \mathrm{cpm}$, and the aliquot with lead contained $20,800 \mathrm{cpm}$. Column, $2 \times 55 \mathrm{~cm}$; flow rate, $7.8 \mathrm{ml} / \mathrm{hr}$; fraction volume, $3.9 \mathrm{ml}$.

synthesis was much greater than the inhibition of ferritin synthesis.

Influence of bipyridine on intracellular iron partition. Table VII shows the results of incubation of equal aliquots of marrow cells with transferrinbound iron in the absence of and in the presence of $5 \times 10^{-4}$ м 2,2'-bipyridine. Bipyridine "trapped" intracellular ferrous iron with a small increase in the low molecular weight fraction. There was marked inhibition of synthesis of hemoglobin and ferritin by bipyridine. The tatal uptake of iron in the presence of bipyridine was $41 \%$ of that of the control.

TABLE VII

The Effect of Bipyridine on Cellular ${ }^{59} \mathrm{Fe}$ Partition

\begin{tabular}{|c|c|c|c|c|c|c|c|c|c|c|c|c|c|}
\hline \multirow[b]{3}{*}{ Control } & \multirow{3}{*}{$\begin{array}{c}\text { Time } \\
\min \\
60\end{array}$} & \multicolumn{2}{|c|}{ Total uptake* } & \multicolumn{2}{|c|}{ Stroma } & \multicolumn{2}{|c|}{ Microsomes } & \multicolumn{2}{|c|}{$\begin{array}{c}\text { Main } \\
\text { hemoglobin }\end{array}$} & \multicolumn{2}{|c|}{ Total ferritin $\ddagger$} & \multicolumn{2}{|c|}{$\begin{array}{c}\text { Low } \\
\text { molecular } \\
\text { weight iron }\end{array}$} \\
\hline & & $c p m$ & $\%$ & $c p m$ & $\%$ & $c p m$ & $\%$ & $c p m$ & $\%$ & $c p m$ & $\%$ & $c p m$ & $\%$ \\
\hline & & 225,991 & 100 & 85,974 & 37.9 & 46,776 & 20.6 & 69,379 & 30.7 & 37,244 & 16.4 & 1,468 & 0.65 \\
\hline $5 \times 10^{-4}$ & & & & & & & & & & & & & \\
\hline bipyridine & 60 & 93,522 & 100 & 57,046 & 60.9 & 25,388 & 27.1 & 2,244 & 2.4 & 7,185 & 7.7 & 1,589 & 1.7 \\
\hline
\end{tabular}

* Calculated for $1 \times 10^{9}$, nucleated marrow cells.

$\ddagger$ Determined by immunoprecipitation without prior ultracentrifugation. 


\section{DISCUSSION}

This report describes the partition of intracellular iron after incubation of canine marrow cells with transferrin-bound ${ }^{59} \mathrm{Fe}$. Four major fractions were obtained: stroma, microsomes, hemoglobin, and nonhemoglobin iron (fraction I). Fraction I was further fractionated into three iron-containing components : a small amount of hemoglobin not bound to cation or anion exchange columns, ferritin and low molecular weight iron. Lysis of the marrow cells with buffer at $\mathrm{pH} 8.6$ resulted in less fraction I than perviously reported (4). After short periods of incubation (3-8 $\mathrm{min}$ ) the majority of the ${ }^{59} \mathrm{Fe}$ was found in the particulate fractions (stroma and microsomes). There was also a considerable amount in the main hemoglobin fraction. Chase experiments performed by incubation for an additional $75 \mathrm{~min}$ without ${ }^{59} \mathrm{Fe}$ showed a large increase in the amount of ${ }^{59} \mathrm{Fe}$ in the main hemoglobin fraction. Essentially all of this radioactive iron came from the particulate fraction. The low molecular weight iron in fraction I showed a decrease in activity during the chase, but there was no significant decrease in the activity of the other components of fraction I. With incubation times of only $3 \mathrm{~min}, 48 \%$ of the ${ }^{59} \mathrm{Fe}$ in the not ultracentrifuged supernatant was found to be in the hemoglobin (average of four experiments). Therefore, these experiments do not indicate the existence of a soluble, intracellular iron protein precursor of hemoglobin.

Greenough, Peters and Thomas reported evidence for the existence of an intracellular iron protein precursor for hemoglobin synthesis (4). At all incubation times they found a larger proportion of ${ }^{59} \mathrm{Fe}$ in fraction I than was observed in the present experiments. In their experiments ferrous citrate ${ }^{59} \mathrm{Fe}$ was added directly to the marrow incubation flask. Adding iron in this fashion causes more iron to be bound to the stroma than when ${ }^{59} \mathrm{Fe}$ bound to transferrin is used as in the present experiments (2). For cell lysis they used distilled water as did other investigators who have reported evidence for the existence of a hemoglobin precursor in the lysate (3, $7)$. As shown in the present experiments, fraction I obtained by water lysis contained a much greater amount of the cellular iron than that obtained by buffer lysis. The findings by Greenough, Peters, and Thomas of larger amounts of fraction I and a higher fraction $I$ to hemoglobin ratio appears explained by the greater nonspecific stromal binding of the ferrous citrate followed by an increased splitting-off of low molecular iron by water lysis. The present experiments do show a decrease in the low molecular weight iron components of fraction I in chase experiments. The total amount of ${ }^{59} \mathrm{Fe}$ in this low molecular weight fraction is very small at any given time. However, this fraction may be turning over rapidly and thus serve as a principal pathway of movement of iron from stroma to the site of synthesis of hemoglobin.

In the previous study, ferritin was not identified in the soluble fraction of the marrow cell lysate (4). This fraction was prepared by ultracentrifugation which results in loss of ferritin as pointed out by Zail, Charlton, Torrance, and Bothwell (7) who did find ferritin in fraction I. An iron-containing fraction was found that appeared to differ from liver ferritin by electrophoresis, but Alfrey, Lynch, and Whitley (17) and Gabuzda and Gardner (18) have demonstrated a difference in the electrophoretic mobility of marrow ferritin and ferritin obtained from liver or spleen. The present immunoprecipitation studies show that ultracentrifugation of the lysate resulted in the loss of about 55 to $60 \%$ of the ferritin from the soluble fraction. The ferritin remaining in the soluble fraction was readily separated by Sephadex chromatography. In chase experiments we found, as did Zail et al. (7) that the amount of ${ }^{59} \mathrm{Fe}$ in ferritin did not change. However, in the presence of a large stromal iron pool, the finding of a persistence of the label in the ferritin in short-term chase experiments does not exclude a turnover of the iron in this compound. Mazur and Carleton (9) found that in the reticulocyte, after reincubation for 1 $\mathrm{hr}$ in unlabeled medium, there was a release of iron from the ferritin with a concomitant degradation of the protein moiety. Since we did not determine the specific activity of the iron in the ferritin before and after the chase, we cannot estimate the contribution of ${ }^{59} \mathrm{Fe}$ for heme synthesis by turnover of ferritin. Our experiments in the first $8 \mathrm{~min}$ of incubation show no buildup of ${ }^{59} \mathrm{Fe}$ in ferritin before the label appears in hemoglobin. The two compounds are labeled in parallel with hemoglobin showing the faster rate. It appears that iron leav- 
ing the stromal pool need not pass through ferritin before it can be utilized for heme synthesis.

The effect of lead on the partition of intracellular iron appeared to depend on the concentration of lead employed. High concentrations of lead reduced strikingly the total uptake of ${ }^{59} \mathrm{Fe}$ by marrow cells with a corresponding decrease of ${ }^{59} \mathrm{Fe}$ in all fractions, but particularly the hemoglobin fraction. Brief exposure to a lower concentration of lead did not inhibit ${ }^{59} \mathrm{Fe}$ uptake by the cell. It did, however, produce a moderate inhibition of hemoglobin synthesis with an increase of ${ }^{59} \mathrm{Fe}$ uptake into ferritin and the "inorganic" iron fraction. Chase experiments showed that low concentration of lead inhibited the movement of ${ }^{59} \mathrm{Fe}$ from the stromal fraction into the soluble intracellular compartment. Hemoglobin synthesis was reduced by $50 \%$, whereas ferritin synthesis showed minimal inhibition. Evidently lead can interfere with the metabolism of iron by marrow cells at a number of sites, but the greatest inhibition is always in hemoglobin synthesis.

Marrow cells were incubated with bipyridine in order to "trap" the intracellular ferrous iron. There was marked inhibition of hemoglobin synthesis as had been observed by others $(9,19)$. Bipyridine also caused inhibition of ferritin synthesis and an accumulation of iron in the low molecular weight fraction. The fact that bipyridine blocked both hemoglobin and ferritin synthesis suggests that ferrous iron within the cell is the source of iron for both hemoglobin and ferritin synthesis.

\section{ACKNOWLEDGMENTS}

We are grateful for the excellent technical assistance of Mrs. Peggy M. Castaneda, Mr. T. C. Graham, and Mrs. Judy Lidstrom.

Dr. E. Donnall Thomas is a recipient of Research Career Award 1-K6-AI-2425 from the National Institute of Allergy and Infectious Diseases of the National Institutes of Health, U. S. Public Health Service. This work was supported by grant AM 07898 from the $\mathrm{Na}$ tional Institutes of Health, U. S. Public Health Service.

\section{REFERENCES}

1. Walsh, R. J., E. D. Thomas, S. K. Chow, R. G. Fluharty, and C. A. Finch. 1949. Iron metabolism. Heme synthesis in vitro by immature erythrocytes. Science. 110: 396.
2. Jandl, J. H., J. K. Inman, R. L. Simmons, and D. W. Allen. 1959. Transfer of iron from serum iron-binding protein to human reticulocytes. J. Clin. Invest. 38: 161.

3. Allen, D. W., and J. H. Jandl. 1960. Kinetics of intracellular iron in rabbit reticulocytes. Blood. 15: 71.

4. Greenough, W. B., III, T. Peters, Jr., and E. D. Thomas. 1962. An intracellular protein intermediate for hemoglobin formation. J. Clin. Invest. 41: 1116.

5. Faber, M., and I. Falbe-Hansen. 1959. Nonhaem iron in erythrocytes as a precursor for haemoglobin. Nature. 184: 1043.

6. Falbe-Hansen, I., and K. Lothe. 1962. In vivo incorporation of ${ }^{59} \mathrm{Fe}$ into nonhem iron and hemoglobin of red blood cells. Acta Physiol. Scand. 54: 97.

7. Zail, S. S., R. W. Charlton, J. D. Torrance, and T. H. Bothwell. 1964. Studies on the formation of ferritin in red cell precursors. J. Clin. Invest. 43: 670.

8. Bessis, M. C., and J. Breton-Gorius. 1957. Iron particles in normal erythroblasts and normal and pathological erythrocytes. J. Biophys. Biochem. Cytol. 3: 503.

9. Mazur, A., and A. Carleton. 1963. Relation of ferritin iron to heme synthesis in marrow and reticulocytes. J. Biol. Chem. 238: 1817.

10. Granick, S. 1946. Ferritin: Its properties and significance for iron metabolism. Chem. Rev. 38: 379.

11. Yakulis, V. J., and P. Heller. 1959. Rapid slide technic for double diffusion agar precipitin test. $\mathrm{Am}$. J. Clin. Pathol. 31: 323.

12. Poulik, M. D. 1957. Starch gel electrophoresis in a discontinuous system of buffers. Nature. 180: 1477.

13. Myhre, E. 1964. Iron uptake and hemoglobin synthesis by human erythroid cells in vitro. Scand. J. Clin. Lab. Invest. 16: 212.

14. Cawley, L. P., W. L. Goodwin, D. R. Schneider, and L. Eberhardt. 1965. Electrophoretic and immunologic studies of non-hemoglobin erythrocyte proteins (NHEP). Federation Proc. 24: 615.

15. Laurell, C. B. 1947. Studies on the transportation and metabolism of iron in the body. Acta Physiol. Scand. 14 (Supl. 46) : 1 .

16. Granick, S. 1954. Iron metabolism. Bull. N. Y. Acad. Med. $30: 81$.

17. Alfrey, C. P., Jr., E. C. Lynch, and C. Whitley. 1965. Differences in human ferritin isolated from human bone marrow, reticulocytes, spleen and liver. Blood. 26: 889. (Abstr.)

18. Gabuzda, T. C., and F. H. Gardner. 1967. Observations on $\mathrm{Fe}^{5 \theta}$ labeled bone marrow ferritin. Blood. 29: 770 .

19. Rabinovitz, M., and H. S. Waxman. 1965. Dependence of polyribosome structure in reticulocytes on iron; implication on the tape theory of haemoglobin synthesis. Nature. 206: 897. 